\title{
Research on the Application of "Online and Offline" Collaborative Complementary Model in Programming Design Courses
}

\author{
Lishuang Zhao ${ }^{1, a}$, Heng Chen ${ }^{2, b}$ \\ ${ }^{1}$ College of information science and Technology, Bohai University, Jinzhou, 121013, China \\ ${ }^{2} 78046$ Unit, PLA, Chengdu, 610031 China \\ ajz_zls@163.com, bshur17@163.com
}

Keywords: Practice; rotating classroom; online and offline; teaching mode; innovation

\begin{abstract}
According to personnel training standard of computer professional, review survey the personnel training target, for special courses, reconstruct the practical teaching system, on the specific teaching practice content, carry out the teaching design in a rotating mode of classroom teaching mode, form an effective "online and offline" collaborative model of practical teaching, and carry out the application of the program design courses in teaching, execute teaching design in classroom teaching, according to student's situation rotating search rotary type teaching for practical teaching, evaluate the extra-curricular classroom for timely feedback and guidance, according to the students' situation of local conditions to modify, update, design teaching plan, grasp the teaching direction, in order to improve the students' practical innovation ability.
\end{abstract}

\section{Introduction}

With the advent of the information age and the learning society, competition is becoming increasingly fierce in the world, and the cultivation of talents with innovative consciousness and practical ability becomes more and more popular in the field of higher education. Therefore, all countries are actively carrying out the reform of higher education, which is committed to developing the high quality talents that meet the needs of social development [1]. The cultivation of practical ability of college students has become one of the hot issues of concern.

In order to achieve high quality professional personnel training, display students' engineering practice ability and innovative ability training, enhance students' ability of entrepreneurship and employment, our school began to formulate and implement undergraduate talent training program since 2011, according to the professional nature, school experience and historical age, status of teaching staff, society of professional personnel training requirements and the students' basic differences, determine the training objectives of diversified talents. And especially point out that: in order to improve the students' ability of entrepreneurship and employment, student should be in line with the social practice in order to improve students' practical ability.

\section{Problems in Practical Teaching of Computer Course}

At present, the research on the development of students' practical ability in computer science are concentrated on the reform of curriculum teaching and experimental teaching mode. The following problems exist: (1) The concept is weak, and for a long time, our country's colleges and universities "weight theory, light practice, weight knowledge and light ability", under the guidance of this kind of education idea, students think, high school should be based on teaching theory, practice teaching assistant. Theoretical teaching reflects the academic, practical teaching is a part of the theory of teaching or supplement. Therefore, from teacher to students, from experiment to practice, from software to hardware, practical teaching has always been in a weak position [2]. (2) The quality of students, with the expansion of enrollment scale, higher education has become a popular education, students quality is far better than before, couple with the development of new technologies in the field of computer science, hours of each course relative reduction, the lack of classroom teaching 
content, practice is also more fragmented, which leads to the improvement of the teaching method and mode, so as to adapt to the current situation in colleges and universities. (3) The shortage of teaching resources, shortage of teacher's academic exchanges, and the shortage of new professional teachers, the teaching resources are relatively limit. In a certain degree, the academic exchange of teachers between different schools are much less, and the gap between teachers is very high in a certain extent, which leads to a low level of practical teaching. (4) Lack of interaction with social force, the change of the personnel training program has influenced the change of the structure of the teachers in colleges and universities, and the training teachers need period, which leads to the development of teacher training lagging market.

\section{Implementation Scheme Design of the Practical Teaching Mode of "Online and Offline"}

Aiming at the problems in practice teaching, combining with the teaching mode of "rotating class" in our school, around the standard of computer professional personnel training, reconstruction of curriculum system, the formation of an effective "online and offline" teaching mode [3-6], and the application of the program design courses improve students' ability to practice and innovation, the specific operation is shown in Fig. 1:

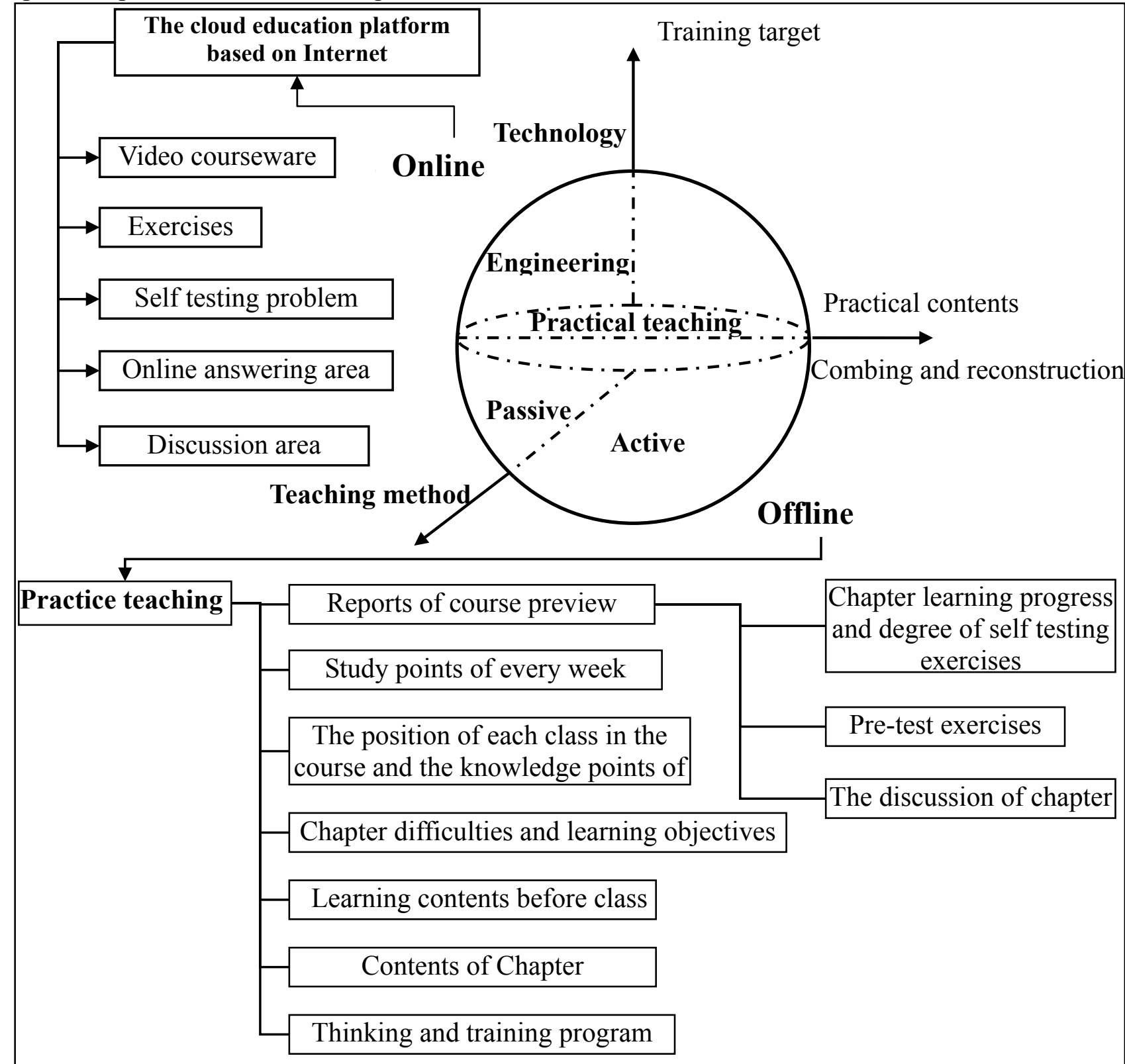

Fig. 1. The concrete implementation scheme design diagram of the practical teaching mode 


\section{Online and offline teaching}

Students can listen to any school teacher lectures at any time, any place through online learning. Online and offline collaborative teaching mode is to refer to the online platform to provide teaching video and knowledge points PPT and other learning resources, students to complete the online resources to learn, and in the classroom (offline) teachers explain the key points of the students, to answer questions, to help students better grasp of knowledge.

\section{Rotating classroom}

"Turning classroom" is to cultivate student's innovation ability and practice ability as the core of the classroom teaching mode, the core problem is "turn" and "move", "turn" means, first is transformation, classroom teaching from the traditional to impart the knowledge center to cultivate students' thinking ability, innovation ability, practical ability as the center; second is transfer method, classroom teaching methods from the traditional indoctrination, cramming change as the heuristic information, inquiry, discussion and case type; third is the swivel, classroom teaching from the traditional with the teacher as the main change to learn the students as the main body. "Dynamic" means, first is interactive, including teacher-student interaction and student-student interaction; the second is using brain, using hands, guide students to both using brain and hands. "Turning classroom" is to "turn" and "move", achieve combination with "transfer" and "move" in the classroom teaching.

\section{Teaching design idea}

The curriculum system structure reconstruction link, for the curriculum system structural reform, also emphasizes "the top level design, the whole optimization", definite the course in the training plan and the boundary. In the course of practice, the content of the course is to be updated [7]. The online and offline learning is combined with the "online", and the students can choose their own teaching courseware at any time. Choose the suitable to different levels of students' exercises and self rated head inspection on the platform to make it easier for students to understand the master degree of knowledge. For classroom teaching, namely "line" teaching, adjust the practice teaching mode, improve teaching content, classroom teaching is not limited to the basic content of the course, consolidate students' knowledge, solve the problem, improve students' understanding of knowledge, cultivate students' ability to grasp practical ability and engineering application ability, teaching can reflect the main factors of the quality of students in different colleges and universities.

4. Curriculum resources development and utilization

Curriculum resources development and utilization: including combine with related teaching materials, training guide, the application of information technology, engineering, network resources, simulation software.

(1) The development of multimedia teaching material and multimedia courseware for teachers and students.

(2) Make full use of resources industry, to provide students with the stages of practical training, so that students in a real environment temper themselves, improve the overall quality of Vocational.

(3) Writing training instruction manual and electronic experiment questions, through the completion of specific tasks to let students experience the fun of learning and achievement.

(4) Make full use of network resources, set up the network curriculum platform and open platform for remote laboratory, achieve high-quality teaching resources sharing.

5. The reform of evaluation system

On the one hand, the school has developed the assessment system for teachers in this teaching environment in order to encourage teachers to work hard, on the other hand, we also have to develop a good evaluation system for the students' achievement [8]. The evaluation of the performance of students in the course is relatively easy, it can be performed online and offline, the former is to the students' online examination as the basis, the latter can refer to the current examination system. 


\section{Course Assessment and Evaluation}

1. Basic evaluation methods

The basic evaluation criteria are as follows shown in Table 1.

Table 1. The basic evaluation standard table

\begin{tabular}{c|c|c}
\hline Serial Number & Assessment Items & Assessment Criteria \\
\hline 1 & $\begin{array}{c}\text { Programming } \\
\text { specifications }\end{array}$ & $\begin{array}{c}\text { Codes are alignment and } \\
\text { notes are complete }\end{array}$ \\
\hline 3 & $\begin{array}{c}\text { The code can run } \\
\text { interface friendly }\end{array}$ & $\begin{array}{c}\text { To run the program through } \\
\text { the C or Java }\end{array}$ \\
\hline 4 & $\begin{array}{c}\text { Data structures are used tips when running } \\
\text { codes }\end{array}$ \\
\hline $\begin{array}{c}\text { to store and operate data } \\
\text { structures }\end{array}$ & $\begin{array}{c}\text { Use the class knowledge of } \\
\text { data encapsulation, } \\
\text { processing }\end{array}$ \\
\hline
\end{tabular}

\section{Constitute of the assessment project}

We examine the students from five parts, including writing assignments, participation degree, group discussion, open assessment and final exam. In every part we examine the students from the number of participation and the records of each part of the assessment, the assessment items are shown in Table 2.

Table 2. Constitute elements of the assessment project

\begin{tabular}{c|c|c|c}
\hline Project & Times & Proportion & Remarks \\
\hline Basic qualities & 5 & $25 \%$ & Assignment \\
\hline Participation degree & & $5 \%$ & Preparation and answers \\
\hline Group discussion & 3 & $15 \%$ & According to the record \\
\hline Open assessment & 1 & $25 \%$ & \\
\hline Final exam & 1 & $30 \%$ & Closed-book exam \\
\hline Total & & $100 \%$ & \\
\hline
\end{tabular}

\section{Assessment requirements:}

- Written work

Ask students biweekly submit a copy of homework, each homework according to the 10 points of the record, the final weight equivalent to $25 \%$ of the written assignments. The Calculation formula is the following formula [9]:

$$
\sum \mathrm{n}(\mathrm{g} \times \mathrm{q}) \times(\mathrm{n} / \mathrm{N})
$$

It's namely written score equal to each assignment of weight scores and multiplying by the commit operation times divide by the total number of times.

- Participation degree

Participate in the degree of the main test of the students to prepare the situation, the classroom answer questions raised by the preview, the enthusiasm of the classroom to speak [10].

- Group discussion

The group discussions are mainly the examination of the students in the interactive training period of the group discussions, and the group's theme, class discussions, the completion of the work of the group. The results of each team member of this score are the same.

- Open assessment

Open assessment mainly examines the student's deep understanding of the course, and obtains the corresponding results through the completion of the open training topics. 


\section{Conclusion}

After a semester of teaching practice, the team members understand and use the spirit of the rotating type of classroom teaching, the following work: (1) around this special course, reconstruction of practical teaching system. (2) The detailed design of the teaching mode of the rotary type is carried out. (3) In the actual classroom teaching implementation of teaching plan design, and according to student time of rotational type teaching of teaching practice exploration. (4) The feedback and guidance of the extra-curricular classes. In practice, we find that there are many problems: (1) online MOOC resources, although many, in the actual teaching of each lesson is also scientific and reasonable to provide students with a large number of auxiliary teaching resources and the corresponding platform, but the students are weak, students have to access, learning resources is too much, the students are obviously insufficient. (2) The number of students are large, the students read more content, so the problem are more, the teacher's feedback can not be timely, but due to the teaching progress and students' situation and many other aspects of the teacher's task is too heavy, resulting in not timely feedback and effective summary.

In short, in the "online and offline" collaborative teaching practice, we have a positive exploration, has a valuable experience, we have to communicate with students in the future teaching, listen carefully to the voice of the students, according to the situation of the students to adjust to local conditions, update, design teaching plan, grasp the teaching direction, and strive to make teaching practice better.

\section{Acknowledgement}

This work is supported by teaching innovation project of Bohai University (No. BDJG-14-QN-A-001), Education Science Planning Foundation project of Liaoning province (No. JG15CB166).

\section{References}

[1] Gu Sujun, "Research on the Application of Interactive Teaching Method of Online and Offline (O2O) in the Course of the University," Teacher, no. 17, pp.89-90, 2014.

[2] Yang Yuxiang, Huang Jiye, Wu Zhanxiong, "Implementation Scheme Design of Hybrid Teaching Mode of the Online and Offline," Course Educational Research, no. 5, pp.3-4, 2015.

[3] Qin Yue, "The Flipped Mode of Online and Offline for Ideological and Political Education of College Student," Modern Educational Technology, vol. 24, no. 5, pp.40-45, 2014.

[4] Li Xiaopeng, "A Teaching Material of Higher Mathematics for Hybrid Teaching of Online and Offline," College Mathematics, vol. 31, no. 3, pp.39-41, 2015.

[5] Li Shuhua, Li Yang, Sang Xinmin, "Blending MOOCs with Face-to-Face Instruction: A Case Study of Systems Science and Santa Fe Institute's MOOCs," Journal of Distance Education, no. 5, pp.17-23, 2014.

[6] Zhang Dai, "Reverse Teaching: Effective Combination of Offline and Online Learning -Taking 'special' Language Education in Kindergarten Teaching Practice as an Example," Education Exploration, no. 11, pp.69-71, 2013.

[7] Liu Jian, Tu Qingsong, Zhang Ling, LI Jun, "Innovation of College Students' Life Education Based on Online and Offline Interaction," Journal of Hubei University of Technology, no. 3, pp.117-120, 2014.

[8] Yang Jiaxing, "Lead in Online Teaching," China Electrifying Education, no. 9, pp.15-18, 2005. 
[9] Zhang Pei, Xiao Tianqing, "Teaching Design and Curriculum Development Based on Network Environment Cooperative Mode Research and Teaching," Curriculum and Teaching, no. 9, pp.60-62, 2007.

[10] Wu Shiying, "The Design of Interactive Learning Strategies of Distance Education on the Online and Offline," Software Guide . Educational Technology, no. 8, pp.36-41, 2008. 